\title{
Pojmové znaky podvodu na DPH v judikatuře Soudního dvora Evropské unie
}

\section{Defining Characteristic of VAT Fraud/Evasion as Established by the Case-law of the Court of Justice of the European Union}

\author{
Karel Brychta ${ }^{*}$, Petr Kupčík ${ }^{* *}$, Vojtěch Procházka ${ }^{* * *}$
}

\begin{abstract}
Abstrakt
Tento prìspèvek prezentuje systematizované závèry z vybraných kličových rozhodnuti SDEU týkajici se odnètí nároku na odpočet DPH (se zamèrením zejména na identifikaci skutkových okolností, keteré mohou svédřit pro naplnèní znakù daňového podvodu/unniku na DPH a identifikaci pravidel a mantinelu pro hodnoceni objektivnich okolností a existence dobré víry na straně daňových subjektü). Z provedeného výzkumu vyplynulo, že SDEU nepodává explicitni a taxativni definici daňového podvodu (úniku) vymezuje však znaky a okolnosti, keteré pro existenci daňovébo podvodu (üniku) svédči. Z judikatury priléhavé ke kladené výzkumné otázce je evidentni, že daňový únik. je možné spojovat s šrokou množinou skutečností. Judikatura SDEU etablovala rovněž testy (nástroje), které bráni nadmèrně extenzivnimu výkladu znakư podvodnébo jednáni. Judikatura SDEU rovněž nelimituje teritoriálni rozsah dañovébo podvodu (relevance i ve vatabu k třetím zemim). Dovozeni účasti daňovébo subjektu na daňovém podvodu je založena na bázi úmyslu a nedbalosti - jinými slovy SDEU vylučuje systém odpovédnosti bez zavinèní. Z judikatury SDEU rovněž plyne znnačná míra diskrece daná tuzemským správním orgánưm prí správě daně a dokazováni relevantnich skutkových okolností. Ačkoli v judikature SDEU nejsou prèdmètné objektivni skutečnosti podrobnèji popsány, lze prostrédnictvím qákladni logiky dojít k qávěru, že pokud cillem vědomostního testu je učinit závèr o vědomosti určitého subjektu o podvodném jednání, tak. jednotlivé objektivni skutečnosti musi být okolnosti ve sfére vlivu dotčenébo subjektu, tudǐ̌ se v qásadě bude jednat o okolnosti vyplývajici z obchodnich vątabu s prímým dodavatelem ri odbèratelem.
\end{abstract}

Klíčová slova

DPH; judikatura SDEU; podvod na DPH; pojmové znaky.

\section{Abstract}

This paper presents systematised conclusions from selected key decisions of the CJEU concerning the disallowance of VAT deductions (focusing in particular on the identification of factual circumstances

* Doc. Mgr. Ing. Karel Brychta, Ph.D., Ústav financí, Fakulta podnikatelská, Vysoké učení technické v Brně / Department of Finance, Faculty of Business and Management, Brno University of Technology, Czech Republic / E-mail: Karel.Brychta@vut.cz / ORCID: 0000-0002-9184-1598 / Research ID: 36975017700

** Ing. Petr Kupčík, Ph.D., Ústav financí, Provozně ekonomická fakulta, Mendelova univerzita, Brno; Odvolací finanční ředitelství, Brno / Department of Finance, Faculty of Business and Economics, Mendel University, Brno, Czech Republic; General Financial Directorate, Brno, Czech Republic / E-mail: petr.kupcik@mendelu.cz / ORCID: 0000-0002-7525-0843 / Research ID: 57192888293

*** Ing. Vojtěch Procházka, absolvent, Fakulta podnikatelská, Vysoké učení technické v Brně; Odvolací finanční ředitelství, Brno / Graduate, Faculty of Business and Management, Brno University of Technology, Czech Republic; General Financial Directorate, Brno, Czech Republic / E-mail: xpproch31@vutbr.cz 
that may indicate the fulfilment of the elements of VAT fraud/evasion and the identification of rules and thresholds for the assessment of objective circumstances and the existence of good faith on the part of taxpayers). From the research carried out, it emerged that the CJEU does not provide an explicit and exhaustive definition of tax fraud (evasion) - however, it defines the features and circumstances that are indicative of the existence of tax fraud (evasion). It is evident from the case law related to the set research question that tax evasion can be associated with a wide range of facts. The CJEU case law has also established tests (tools) which prevent an overly broad interpretation of the elements of fraudulent conduct. CJEU case law also does not limit the territorial scope regarding tax evasion (there is a relevance also in relation to third countries). The presumption of the payer's participation in tax fraud is based on intention and negligence - in other words, the CJEU rules out a system of liability without fault. The case law of the CJEU also shows the considerable degree of discretion given to the domestic administrative authorities in the tax procedure and bearing the burden in proving of relevant facts. Although the CJEU case-law does not describe the objective facts in question in details, it can be concluded through basic logic that, if the purpose of the knowledge test is to conclude that an entity has knowledge of fraudulent conduct, the objective facts in question must be circumstances within the sphere of influence of the entity in question, so that they will in principle be circumstances arising from the business relationship with the direct supplier or customer.

\section{Keywords}

VAT; CJEU Case Law; VAT Frand; Defining Characteristics.

\section{Úvod}

Daň z pridané hodnoty (DPH) je klíčovou neprrímou daní ze spotřeby, jejíž historie je v porovnání s historií daní jako takových zanedbatelně krátká. ${ }^{1}$ Zároveň se však jedná o daň, která je z pohledu řady států, včetně ČR, klíčová náhledem její důležitosti pro státní rozpočet. U této daně (stejně jako v různé míře u ostatních daní) je poukazováno na slabiny, nedostatky, možnosti zneužití a velkou mezeru ve výběru daně² (tj. rozdíl mezi očekávaným a skutečným výběrem). Ta pro rok 2018 dle Evropské komise ${ }^{3}$ v případě DPH činila celkově 140 mld. € s poukazem na to, že dané číslo je stále velmi vysoké navzdory předchozímu pozitivnímu trendu ve snižování; pro rok 2020 bylo navíc očekáváno relativně významné zhoršení (164 mld. €) s ohledem na dopady spojené s pandemií

1 Idea DPH je prripisována německému podnikateli Wilhelmu Von Siemens (20. léta 19. stoletî), první etablování do daňového systému je připisováno „otci DPH“, Maurici Laurému (Francie, 1954).

Blíže viz CHARLET, Alain a Jeffrey OWENS. An International Perspective on VAT. Tax Notes International [online]. 2010, roč. 59, č. 12 [cit. 2.1. 2021]. Dostupné z: https://www.oecd.org/ctp/consumption/46073502.pdf

2 EUROPEAN COMMISSION (2020a). EU VAT GAP. VAT Gap: EU countries lost €140 billion in VAT revenues in 2018, with a potential increase in 2020 due to coronavirus [online]. 10. 9. 2020 [cit. 5. 1. 2021]. Dostupné z: https://ec.europa.eu/commission/presscorner/detail/en/ip_20_1579

3 EUROPEAN COMMISSION (2020b). Study and Reports on the VAT Gap in the EU-28 Member States: 2020 Final Report [online]. [cit. 23. 10. 2020]. Dostupné z: https://ec.europa.eu/taxation_customs/ business/tax-cooperation-control/vat-gap_en 
COVID-19. Dle studie prezentované Evropským parlamentem ${ }^{4}$ je mezera v inkasu DPH $\mathrm{v}$ rámci EU tvořena v průměru $50 \mathrm{mld}$. $€$ tzv. kolotočovými podvody ${ }^{5}$. Dalším negativním aspektem spojeným s fungováním DPH je, že DPH není implementována jednotně, jinými slovy nefunguje ve všech členských státech stejným způsobem. To je důsledkem prokazatelného vlivu lingvistických, kulturních a sociálních faktorů, stejně jako nezanedbatelného vlivu typu právního systému př́islušného státu'. $\mathrm{Na}$ druhou stranu však existující studie prokazují pozitivní dopad DPH na ekonomiky států7. Tento fakt ve spojení s nemožností najít náhradu pro DPH jenom posiluje potřebu reakce normotvůrců na zjištěné nedostatky př́slušnými legislativními změnami s cílem eliminovat nedostatky $\mathrm{v}$ právní úpravě, reagovat na změnu společenských podmínek ${ }^{8}$ a bezesporu i reagovat na aktivity spojené s krácením daně.

V oblasti specifikace pravidel (nejenom) pro DPH pak sehrává jednu z klíčových rolí Soudní dvưr EU (dříve ESD, dále v textu jen SDEU) a jeho judikatura. Ta etabluje pravidla a rámec pro unijně konformní interpretaci a aplikaci právní úpravy ${ }^{9}$, včetně pravidel pro zachování nároku na odpočet, který je nosným principem fungování $\mathrm{DPH}^{10}$. Právo na odpočet DPH jako takové a související podmínky jsou zakotveny v čl. 167 a násl.

4 EUROPEAN PARLIAMENT. VAT fraud: Economic impact, challenges and policy issues [online]. Brussels, 2018 [cit. 23. 10. 2020]. Dostupné z: https://www.europarl.europa.eu/RegData/etudes/ STUD/2018/626076/IPOL_STU(2018)626076_EN.pdf

5 Boj proti podvodům, vyhýbání se daňové povinnosti a zneužití práva je ostatně imanentní součástí směrnice (rozsáhleji viz nap̌r. rozsudek Soudního dvora (třetího senátu) ze dne 6. 6. 2006, Axel Kittel proti Belgickému státu a Belgický stát proti Recolta Recycling SPRL, spojené věci C-439/04 a C-440/04. In: Sbirka rozhodnutí. 2006, s. I-06161.

6 KRISTOFFERSSON, Eleonor. Comparative studies of national law in the EU harmonized VAT. Nordic Tax Journal [online]. 2016, č. 1, s. 29-40 [cit. 15. 1. 2021]. Dostupné z: https://doi.org/10.1515/ ntaxj-2015-0011

7 SIMIONESCU, Mihaela a Lucian-Liviu ALBU. The Impact of Standard Value Added Tax on Economic Growth in CEE-5 Countries: Econometric Analysis and Simulations. Technological and Economic Development of Economy [online]. 2016, roč. 22, č. 6, s. 850-866 [cit. 20.1. 2021]. Dostupné z: https://doi.org/10.384 6/20294913.2016.1244710

8 V tomto ohledu nelze nezmínit významné návrhy změn - viz EUROPEAN COMMISSION (2020). Action Plan on VAT [online]. [cit. 13.3. 2021]. Dostupné z: https://ec.europa.eu/taxation_customs/ business/vat/action-plan-vat_en; či řadu akademických diskusí týkajících se změny koncepce (viz např. TIMMERMANS, Benoît a Wouter M. J. ACHTEN. From value-added tax to a damage and value-added tax partially based on life cycle assessment: principles and feasibility. International Journal of Life Cycle Assessment [online]. 2018, č. 23, s. 2217-2247. Dostupné z: https://doi.org/10.1007/s11367-018-1439-7).

9 GENSCHEL, Philipp a Markus JACHTENFUCHS. How the European Union constrains the state: Multilevel governance of taxation. European Journal of Political Research, 2001, roč. 50, č. 3, s. 293-314, s. 300. ISSN 0304-4130.

Uvedení autoři ve spojení se SDEU a jeho rolí uvádí následující: „While each tax case concerns a particular tax rule in a particular Member State, the resulting case law has a harmonising effect across taxes and Member States because, by providing detailed reasons why the particular rule is (not) in line with EU law, it establishes general principles of acceptable tax policy for the EU as a whole."

10 Směrnice Rady 2006/112/ES ze dne 28. 11. 2006, o společném systému daně z přidané hodnoty, ve znění pozdějších předpisů (viz např. body (5), (7), (13), (30) a (34) Preambule). 
Směrnice Rady 2006/112/ES ${ }^{11}$. V širších souvislostech byly atributy odpočtu DPH popsány např. v rozhodnutí SDEU ve věci Securenta (C-437/06) $)^{12}$, ve kterém bylo mj. konstatováno, že: „nárok na odpočet je nedílnou součástí mechanismu DPH, nemůže být $\boldsymbol{v}$ zásadě omezen [zvýrazněno autory] [...], cílem systému odpočtu zavedenébo šestou smèrnicí je totiž zcela zbavit podnikatele zatízeni DPH, která je splatná nebo byla odvedena v rámci jeho hospodárskeých činností. "Tato premisa a požadavek jsou logické, nebot' zachování nároku na odpočet je, jak již bylo uvedeno shora, klíčovým atributem z hlediska zajištění neutrality DPH. To je konstantně a dlouhodobě potvrzováno i rozhodovací praxí SDEU ${ }^{13}$ s ohledem na to, že společný systém DPH a s tím spojený nárok na odpočet zajišt'ujî neutralitu daňové zátěže všech hospodářských činností bez ohledu na účel nebo výsledky těchto činností, za podmínky, že uvedené činnosti v zásadě samy podléhají DPH (k souvisejícím otázkám a hodnocení viz např. rozsudek SDEU ve věci Gabalfrisa SL a další, spojené př́pady C-110/98 až C-147/98) ${ }^{14}$. Ve spojitosti s uplatněním nároku na odpočet je dlouhodobě „drženým“ a pochopitelným pravidlem i to, že uplatnění nároku na odpočet nestojí pouze na splnění ryze formálních požadavků, ale je podmíněno i fakticitou poskytnutého plněni ${ }^{15}$ a dále splněním hmotněprávních předpokladů (podmínek), kterými jsou poskytování plnění ve vztahu k osobám povinným k dani a užití v rámci ekonomické činnosti ${ }^{16}$.

Nicméně ani naplnění shora uvedených podmínek samo o sobě neznamená automatické přiznání nároku na odpočet: za určitých podmínek může být odňat, resp. nepřiznán. Průlomem v této věci (tedy odepření nároku na odpočet daně i př̀i splnění hmotněprávních a formálních podmínek) je situace, kdy je tento nárok zatížen

11 Čl. 167 a násl. Směrnice Rady 2006/112/ES ze dne 28. 11. 2006, o společném systému daně z přidané hodnoty, ve znění pozdějších prèedpisů.

12 Rozsudek Soudního dvora (čtvrtého senátu) ze dne 13. 3. 2008, Securenta Göttinger Immobilienanlagen und Vermögensmanagement AG proti Finanzamt Göttingen, věc C-437/06. Dostupné z: Sbirka roz̧hodnutí. 2008, s. I-01597.

13 Viz např. rozsudek SDEU ve věci Barlis (C-516/14), ze kterého plyne, že odpočet daně na vstupu má být přiznán, jestliže jsou splněny hmotněprávní požadavky, $i$ když osoby povinné $\mathrm{k}$ dani nevyhověly některým náležitostem formálním, ledaže by porušení formálních náležitostí mělo za následek nemožnost předložení rozhodujícího důkazu o splnění hmotněprávních požadavků. Blíže viz rozsudek Soudního dvora (čtvrtého senátu) ze dne 15. 9. 2016, Barlis 06 - Investimentos Imobiliários e Turísticos SA, věc C516/14. ECLI:EU:C:2016:690.

14 Rozsudek Soudu ze dne 21. 3. 2000, Gabalfrisa SL and Others proti Agencia Estatal de Administración Tributaria (AEAT), spojené prípady C-110/98 až C-147/98. Dostupné z: Sbirka rozhodnutí. 2000, s. I-01577.

15 Tento požadavek determinovaný unijním právem je pochopitelně přejímán i do českého prostředí (viz např. rozsudek NSS ČR ze dne 15. 5. 2007, sp. zn. 2 Afs 177/2006).

16 Rozsudek Soudního dvora (trretího senátu) ze dne 6. 9. 2012, Gábor Tóth proti Nemzeti Adó-és Vámbivatal Észak-magyarorşági Regionális Adó Föigazgatósága, věc C-324/11. ECLI:EU:C:2012:549 (bliže viz bod [26]). 
podvodem, event. je uplatňování podvodně ${ }^{17}$ (k obecnějším otázkám zneužití a odepření nároku na odpočet viz např. notoricky známý rozsudek SDEU ve věci Halifax a dalši $\left.(\mathrm{C}-255 / 02)^{18}\right)$. Byl to opět SDEU, který v rámci své judikatury poskytl rámec (vodítko) pro posouzení toho, zda je možné nárok na odpočet odejmout, resp. nepřiznat - jmenovitě se jedná o nástroj, který je nazýván „Axel Kittel test“. Jde o test, jehož naplnění (rozuměno všech jeho atributů) zakládá povinnost správce daně odepř́ít nárok na odpočet. Při vlastním hodnocení je vhodné dodržet sekvenci stanovených kroků. Je však třeba brát v potaz, že jednotlivé kroky nelze izolovat, stejně tak jako hodnocení souvisejících skutkových okolností, které mohout být (a zpravidla jsou) relevantní pro naplnění více znaků. Ve spojení s aplikací „Axel Kittel testu“ je prováděno hodnocení mj. ve vztahu"

- zjištění a prokázání existence podvodu na DPH;

- zhodnocení objektivních okolností případu (situace);

- zhodnocení opatření přijatých na straně daňového subjektu za účelem vyhnutí se jeho participaci na podvodu na $\mathrm{DPH}^{20}$.

Výchozí premisou, kterou se v zásadě podmiňuje připuštění existence podvodu na $\mathrm{DPH}$, je tzv. „chybějící daň“"21, a to ta, která vznikla na základě daňového podvodu - tj. daňový únik. Daňová ztráta pro veřejné rozpočty totiž nemusí být nutně důsledkem daňového

17 Rozsudek Soudního dvora (třetího senátu) ze dne 21. 6.2012, Mahagében Kftproti Nemzeti Adó-és Vámbivatal Dél-dunántúli Regionális Adó Fóigazgatósága a Péter Dávid proti Nemzeti Adó-és Vámbivatal Észak-alföldi Regionális Adó Föigazgatósága, spojené věci C-80/11 a C-142/11. ECLI:EU:C:2012:373.

18 Rozsudek Soudního dvora (velkého senátu) ze dne 21. 2. 2006, Halifax plc, Leeds Permanent Development Services Ltd a County Wide Property Investments Ltd proti Commissioners of Customs \& Excise, věc C-255/02. Dostupné z: Sbirka roz̧hodnutí. 2006, s. I-01609.

19 Vlastní úprava autory prŕspěvku. Jde o výběr atributů.

20 Rozsudek Soudního dvora (třetího senátu) ze dne 6. 7. 2006, Axel Kittel proti Belgickému státu a Belgický stát proti Recolta Recycling SPRL, spojené věci C-439/04 a C-440/04. Dostupné z: Sbirka roz̧hodnutí. 2006, s. I-06161.

SDEU se v daném rozhodnutí vypořádal i s hodnocením dopadu absolutní neplatnosti smlouvy v rovině soukromoprávní na zachování nároku na odpočet. Rozhodnutí SDEU má následující znění: „Pokud je dodáni uskutečnèno pro osobu povinnou k dani, která nevéděla a nemobla védèt, že dotyčné plnèni je součástípodvodu spáchanébo prodávajícím, je tréba článek 17 sesté smèrnice Rady 77/388/EHS ze dne 17. kevétna 1977 o harmonizaci právnich prèdpisu členských států týkajicich se daní zobratu - Společný systém dané zpridané hodnoty: jednotný základ daně, ve znèni smèrnice Rady 95/7/ES ze dne 10. dubna 1995, vykládat v tom smyslu, že bráni pravidlu vnitrostátního práva, podle keterébo zrušeni smlouvy o prodeji na základè ustanoveni občanského práva, které zpuisobuje absolutni neplatnost této smlouvy pro rozpor s verejným poŕádkem z dìvodu protiprávnosti na strané prodávajícího, vede ke ztrátě nároku na odpočet daně z. pridané hodnoty odvedené touto osobou povinnou $k$ dani. V tomto obledu není relevantní otázka, zda uvedená neplatnost vyplývá z.podvodu na dani zpridané bodnoty, nebo zjiných podvodü.

Naopak, pokud je s priblédnutim k objektivnim skutečnostem prokázáno, že dodáníje uskutečnèno pro osobu povinnou k dani, která véděla nebo měla vědět, že se svým nákupem účastni plnèni, které je součástí podvodu na dani zpridané hodnoty, je vécí vnitrostátního soudu odmítnout takové osobé povinné k dani priznat nárok na odpočet."

Pro srovnání viz z novějších rozsudků NSS ČR např. rozsudek NSS ČR ze dne 30.7. 2020, sp. zn. 10 Afs $173 / 2017$.

21 Termín chybějící daň je termínem etablovaným v českém prostředí, zrejejmě ve spojitosti s povinností správce daně určit výši „,chybějící daně“. Judikatura ESD užívá termín „daňový únik“, obecněji lze hovořit o tzv. „narušení neutrality daně“. 
úniku, může se jednat o důsledek standardního chodu podnikání ve spojení s úpadkem podnikatelského subjektu, nastoupení druhotné platební neschopnosti, atd. ${ }^{22} \mathrm{~V}$ návaznosti na první shora uvedený bod je povinností správce daně prokázat existenci nestandardních okolnostîi ${ }^{23} \mathrm{~s}$ tím, že samotná existence daňového podvodu a existence nestandardností v řetězci neznačí samy o sobě a priori možnost odnětí nároku na odpočet ${ }^{24}$. Ve spojení s odepřením nároku na odpočet tíží správce daně důkazní břemeno i ohledně prokázání toho, že s ohledem na objektivní okolnosti daňový subjekt věděl, nebo mohl a měl vědět, že se účastní plnění zatíženého (spojeného) s daňovým podvodem ${ }^{25}$. Prokázání existence daňového úniku v důsledku podvodu, stejně jako existence „podezřelých“ objektivních okolností však samy o sobě neznamenají odepření nároku na odpočet. Daňový subjekt může odepření nároku na odpočet čelit prokázáním toho, že přijal adekvátní opatření, kterými brojil proti jeho zapojení do podvodu na $\mathrm{DPH}^{26}$. Judikatura, včetně té české, v tomto ohledu etablovala řadu omezení, které brání nadužívání odnětî nároku na odpočet za užití akcentu na dosažení daňového inkasa. Jedná se o následujícíi ${ }^{27}$

a) Prověřování věrohodnosti obchodních partnerů v řetězci nelze extenzivně a bezmezně rozšiřovat (na místě je tak otázka určení toho, do jakého stupně je to možné).

22 Tento aspekt ve spojení s pandemií COVID-19 a jeho dopady vyznívá obzvláště aktuálně.

23 Viz např. rozsudek NSS ČR ze dne 15. 2. 2017, sp. zn. 1 Afs 53/2016.

24 Rozsudek Soudního dvora (třetího senátu) ze dne 6. 12. 2012, Bonik EOOD proti Direktor na Direkcija „Obそ̌alvane i upravlenie na izpalnenieto" - Varna pri Centralno upravlenie na Nacionalnata agencija za prichodite, věc C285/11. ECLI:EU:C:2012:774.

Bod [41] předmětného rozsudku uvádí: „S režimem nároku na odpočet upraveným v uvedené směrnici není naopak slučitelné sankcionovat nepriznáním tohoto nároku osobu povinnou ke dani, která nevédéla nebo nemobla védèt, že dotyčné plnèni bylo součástí daňovébo uniku, keterébo se dopustil dodavatel, nebo že jüné plnèní, které je součástí dodavatelského retézce a prèdcházi dodáni uskuténnènému uvedenou osobou povinnou k dani nebo po ném následuje, bylo provázeno únikem ve vz̧tabu k. DPH (v tomto smyslu viz výše uvedené rozsudky Optigen a dalši, body 52 a 55, Kittel a Recolta Recycling, body 45, 46 a 60, jakož i Mahagében a Dávid, bod 47)."

25 Rozsudek Soudního dvora (třetího senátu) ze dne 6. 12. 2012, Bonik EOOD proti Direktor na Direkcija „Ob̌̌alvane i upravlenie na izpalnenieto" - Varna pri Centralno upravlenie na Nacionalnata agencija za prichodite, věc C285/11. ECLI:EU:C:2012:774.

Bod [43] daného rozsudku uvádí následující: „V z̧hledem k tomu, že odmítnutí nároku na odpočet je výjimkou ze základni zásady, kterou tento nárok predstavuje, je tedy na príslušných dañových orgánech, aby právně dostačujícím zpuisobem prokázaly objektivni okolnosti umožñujici učinit závèr, že osoba povinná k dani védéla nebo musela védèt, že plnèni uplatñované k oduivodnèni nároku na odpočet bylo součástí podvodu, kterébo se dopustil dodavatel či jiný subjekt operujici v dodavatelském rètézci na vstupu nebo výstupu..."

26 Rozsudek Soudního dvora (třetího senátu) ze dne 27. 9. 2007, The Queen, na žádost Teleos plc a dalši proti Commissioners of Customs \& Excise, věc C-409/04. Dostupné z: Sbirka rozhodnutí. 2007, s. I-07797.

$\mathrm{V}$ bod [65] předmětného rozsudku se uvádí: „... neni v rozporu s právem Společenství požadovat, aby dodavatel prijal všechna opatření, keterá po nèm mohou být rozumně požadována, aby zajistil, že operace, kterou provádi, jej nepovede ke účasti na daňovém podvodu (viz, co se týce podvodu „kolotočovébo“ typu, výse uvedené rozsudky Federation of Technological Industries a dalši, bod 33, jakož i Kittel a Recolta Recycling, bod 51)."

K dané otázce viz rovněž body [58]-[62] Rozsudku Soudního dvora (třetího senátu) ze dne 21. 6. 2012, Mahagében Kft proti Nemzeti Adó- és Vámbivatal Dél-dunántúli Regionális Adó Fóigazgatósága a Péter Dávid proti Nemzeti Adó- és Vámbivatal Észak-alföldi Regionális Adó Föigargatósága, spojené věci C80/11 a C142/11. ECLI:EU:C:2012:373.

27 Rozsudek NSS ČR ze dne 30. 1. 2018, sp. zn. 5 Afs 60/2017. 
b) Znakem daňového podvodu na DPH je, že jeden z účastníků daň neodvede a další si ji odečte; to však neznamená, že za ,jednoho“ a „dalšího“ lze automaticky považovat „kteréhokoli“ $z$ účastníků v řetězci obchodů. To se váže k potřebě vymezit to, do jakého stupně je založena objektivní daňová odpovědnost, jaké faktory sehrávají při hodnocení roli a jaké skutkové okolnosti by měly být předmětem hodnocení.

c) Podmínkou správně stanovené daně je to, že daň není automaticky vyměřována subjektu, u nějž je to z hlediska vymahatelnosti práva jednodušší a je zjevné, že daňový výnos bude zaručen, event. zaručen s vyšší mírou pravděpodobnosti.

Shora uvedený výčet atributů svědčí o komplexnosti a náročnosti problematiky odnětí/nepřiznání nároku na odpočet DPH. Dokladem toho je ostatně i sama rozsáhlost související judikatury SDEU, která obsahuje mantinely zachování/odnětí nároku na odpočet DPH z důvodu existence podvodu na DPH.

\section{Cíl a metodika}

Cílem tohoto př́spěvku, který je zamýšlen jako základ pro navazující a rozšiřující analýzy, bylo identifikovat a systematizovat závěry z vybraných klíčových rozhodnutí SDEU týkající se odnětí nároku na DPH: jmenovitě ty, které se týkají atributů ve spojení s vědomostním testem (viz text príspěvku výše). Základní výzkumné otázky byly pro účely realizovaného výzkumu a ve spojení s poznatky uvedenými v předchozí kapitole stanoveny následovně:

1. Které obecné skutečnosti mohou svědčit pro naplnění znaků daňového podvodu/úniku na DPH?

2. Jaká jsou základní pravidla a mantinely vymezené judikaturou SDEU pro hodnocení objektivních okolností a pro hodnocení existence dobré víry na straně daňových subjektů?

Provedený výzkum byl realizován jako výzkum kvalitativní, jehož primárním cílem bylo porozumět př́íslušnému fenoménu ${ }^{28}$ (tj. institutu nároku na odpočet DPH ve spojení $\mathrm{s}$ aspekty vědomostního testu), případně př́islušným souvislostem a vazbám. Užitými metodami výzkumu byly př́padová studie a zakotvená teorie; základními technikami sběru dat pak obsahová analýza textu. Předmětem výzkumu byla příslušná právní úprava a vybraná relevantní judikatura SDEU (pro dílčí aspekty částečně vybraná judikatura NSS ČR ${ }^{29}$. Článek byl zpracován podle stavu platného a účinného k 1.1. 2021.

28 DISMAN, Miroslav. Jak se vyrábi sociologická znalost: príručka pro uživatele. 4., nezměn. vyd. Praha: Karolinum, 2011.

29 Zdrojem judikatury SDEU (event. Evropského soudního dvora) byl jak níže uvedený systém ASPI, tak i Eur-lex. Viz Access to European Union law. EUR-LEX [online]. [cit. 22. 2. 2021]. Dostupné z: https:// eur-lex.europa.eu/homepage.html

Zdrojem právních předpisů a judikatury NSS ČR byl právní informační systém ASPI (Wolters Kluwer (2021). ASPI (automatizovaný systém právních informací). [databáze]. Copyright (C) 2000-2021 Wolters Kluwer CR, a. s.); alternativně pak webové stránky NSS ČR (2021). Nejvy šśi spráuni soud ČR. Rozhodovaci činnost / Rozhodnuti správnich soudu. [online]. [cit. 22.3. 2021]. 


\section{Judikatura SDEU a její závěry}

Judikatura SDEU etablovala povinnost odmítnout nároky vyplývající ze Směrnice o DPH, které jsou uplatňovány podvodně nebo zneužívajícím způsobem a to bez ohledu na to, zda se jedná o nárok na odpočet, osvobození nebo vrácení DPH související s dodáním zboží uvnitř EU ${ }^{30}$. Imperativ odmítnutí je odrazem toho, že boj proti daňovým únikům, vyhýbání se daňovým povinnostem a bránění případnému zneužívání je cílem, který unijní právo uznává a aprobuje. SDEU v tomto ohledu konstantně judikuje, že právní subjekty se nemohou dovolávat unijních právních norem podvodně, či zneužívajícím způsobem ${ }^{31}$. SDEU rovněž uzavírá, že nevedení zákonem stanovené evidence (účetnictví, evidence prijatých a vydaných faktur) lze považovat za součást daňového úniku na $\mathrm{DPH}^{32}$. Pokud naplňuje znaky daňového úniku posledně uvedené, pak tím spíše naplňují znaky daňového podvodu/úniku aspekty závažnější, kterými jsou zejména:

- předložení falešných faktur nebo falešných prohlášení, jakož i jakákoliv jiná manipulace s důkazy, která může zabránit správnému výběru daně a v důsledku toho ohrozit řádné fungování systému $\mathrm{DPH}^{33}$;

- podvodné jednání osoby povinné $\mathrm{k}$ dani v podobě zatajení dodání a/nebo zatajení př́j ů $^{34}$;

30 Rozsudek Soudního dvora (prvního senátu) ze dne 18. 12. 2014, Staatssecretaris van Financiën proti Schoenimport „Italmoda“ Mariano Previti vof a Turbu.com BV Turbu.com Mobile Phone's BV proti Staatssecretaris van Financiën, spojené věci C-131/13, C-163/13 a C-164/13. ECLI:EU:C:2014:2455.

31 Usnesení Soudního dvora (desátého senátu) ze dne 3. 9. 2020, Vikingo Fövállalkozó Kft. proti Nemzeti Adó- és Vámbivatal Fellebbviteli Igazgatósága, věc C-610/19. Dosud nezveřejněno ve sbírce rozhodnutí. ECLI:EU:C:2020:673 (blíže viz bod [50]).

Rozsudek Soudního dvora (pátého senátu) ze dne 16. 10. 2019, Glencore Agriculture Hungary Kft. proti Nemzeti Adó- és Vámbivatal Fellebbviteli Igazgatósága, věc C-189/18. Dosud nezveřejněno ve sbírce rozhodnutí. ECLI:EU:C:2019:861 (blǐže viz bod [34]).

Rozsudek Soudního dvora (třetího senátu) ze dne 6. 7. 2006, Axel Kittel proti Belgickému státu a Belgický stát proti Recolta Recycling SPRL, spojené věci C-439/04 a C-440/04. Dostupné z: Sbirka rozhodnutí. 2006, s. I-06161 (blíže viz body [54] a [55]).

32 Rozsudek Soudního dvora (sedmého senátu) ze dne 5. 10 2016, ET „Maja Marinova“ proti Direktor na Direkcia „Obžalvane i danačno-osiguritelna praktika“ "Veliko Tarnovo pri Centralno upravlenie na Nacionalnata agencia za prihodite, věc C-576/15. Dosud nezveřejněno ve sbírce rozhodnutí. ECLI:EU:C:2016:740 (blíže viz bod [39]); rozsudek Soudního dvora (sedmého senátu) ze dne 28. 7. 2016, trestní rízeníproti Giuseppemu Astoneovi, věc C-332/15. ECLI:EU:C:2016:614 (blíže viz bod [56]).

Shora uvedený závěr je naprosto legitimní, nebot' samotná Směrnice o DPH ve svém čl. 242 ukládá povinnost vést k dani vhodné účetnictví, článek 244 Směrnice o DPH podřizuje tyto osoby povinnosti uchovávat všechny faktury a článek 250 odst. 1 Směrnice o DPH ukládá osobám povinným k dani povinnost podat přiznání $\mathrm{k}$ dani, které obsahuje všechny údaje potřebné $\mathrm{k}$ výpočtu částky splatné $\mathrm{DPH}$.

33 Rozsudek Soudního dvora (velkého senátu) ze dne 7. 12. 2010, trestní rízení proti R., věc C-285/09. Dostupné z: Sbirka roz̧hodnutí. 2010, s. I-12605 (blíže viz bod [48]).

34 Rozsudek Soudního dvora (sedmého senátu) ze dne 5. 10. 2016, ET „Maja Marinova“ proti Direktor na Direkecia „Obžalvane i danačno-osiguritelna praktika" Veliko Tarnovo pri Centralno upravlenie na Nacionalnata agencia za prihodite, věc C-576/15. Dosud nezveřejněno ve sbírce rozhodnutí. ECLI:EU:C:2016:740 (blíže viz bod [42]). 
- nepodání daňových přiznání, které lze nicméně považovat pouze za „neprímýc“ důkaz o daňovém úniku (neprokazuje nevyvratitelným způsobem, že $\mathrm{k}$ daňovému úniku při odvodech DPH skutečně došlo) ${ }^{35}$; okolnosti týkající se nesplnění formálních povinností (nepodání daňového přiznání $\mathrm{k}$ DPH, neevidování daňových dokladů a neodvedení částky daně správním orgánům) jsou však způsobilé prokázat nejjednodušší případ daňového podvodu, kdy osoba povinná $\mathrm{k}$ dani záměrně neplní své formální povinnosti s cílem vyhnout se zaplacení daně̉ ${ }^{36}$.

Ve vztahu k teritoriálnímu aspektu daňového podvodu/úniku na dani SDEU opakovaně judikuje, že existence podvodného řetězce (event. podvodu) není omezena teritoriálně; tedy $\mathrm{k}$ daňovému podvodu $\mathrm{v}$ rámci dodavatelsko-odběratelského řetězce může docházet i v jiném členském státě ${ }^{37}$, stejně jako ve třetí zemi ${ }^{38}$.

$\mathrm{Na}$ druhou stranu SDEU v rámci své judikatury brojí proti př́liš extensivnímu výkladu znaků daňového úniku: platí, že pokud správce daně na základě toho, že se vystavitel faktur nebo jiné subjekty vystupující na předcházejících stupních dodavatelského řetězce dopustili daňového úniku nebo nesrovnalostí, dospěje k závěru, že se naúčtovaná plnění uplatňovaná k odůvodnění nároku na odpočet uskutečnila, nárok na odpočet může odepř́t pouze tehdy, pokud na základě objektivních okolností, a aniž by po př́jemci faktur požadoval ověření, která mu nepř́islušejí provádět, prokáže, že tento př́ijemce věděl nebo měl vědět, že tato plnění jsou součástí úniku na $\mathrm{DPH}^{39}$. Zároveň SDEU poukazuje na to, že pokud je prokázáno, že došlo k dodání zboží, nelze mít za to, že skutečnost, že se řetězec plnění vedoucí k těmto dodáním z ekonomického hlediska nejeví jako smysluplný či náležitě opodstatněný, nebo okolnost, že některý z účastníků tohoto řetězce nesplnil své daňové povinnosti, jsou samy o sobě znakem daňového úniku ${ }^{40}$.

35 Rozsudek Soudního dvora (druhého senátu) ze dne 19. 10. 2017, SC Paper Consult SR L proti Direcția Regională a Finanţelor Publice Cluj-Napoca a Administrația Județeană a Finanţelor Publice Bistrița Năsăud, věc C-101/16. ECLI:EU:C:2017:775 (blíže viz bod [56]).

36 Rozsudek Soudního dvora (sedmého senátu) ze dne 28. 7. 2016, trestní rízení proti Giuseppemu Astoneovi, věc C-332/15. ECLI:EU:C:2016:614 (blíže viz bod [55]).

37 Rozsudek Soudního dvora (prvního senátu) ze dne 18. 12. 2014, Staatssecretaris van Financiën proti Schoenimport „Italmoda“ Mariano Previti vof a Turbu.com BV Turbu.com Mobile Phone's BV proti Staatssecretaris van Financiën, spojené věci C-131/13, C-163/13 a C-164/13. ECLI:EU:C:2014:2455 (blíže viz bod [69]).

38 Rozsudek Soudního dvora (pátého senátu) ze dne 17.12. 2020, BAKATI PLUS Kereskedelmi és Szolgáltató Kft. proti Nemæeti Adó- és Vámbivatal Fellebbviteli Igazgatósága, věc C-656/19. Dosud nezveřejněno ve sbírce rozhodnutí. ECLI:EU:C:2020:1045 (blíže viz bod [83]).

Rozsudek Soudního dvora (desátého senátu) ze dne 17. 10. 2019, Unitel Sp. z o.o. w Warszawie proti Dyrektor Izby Skarbowej w Warszawie, věc C-653/18. ECLI:EU:C:2019:876 (blíže viz bod [37]).

39 Usnesení Soudního dvora (desátého senátu) ze dne 3. 9. 2020, Vikingo Fóvállalkozó Kft. proti Nemąeti Adó- és Vámbivatal Fellebbviteli Igargatósága, věc C-610/19. ECLI:EU:C:2020:673 (blíže viz bod [58]); viz rovněž Usnesení Soudního dvora (devátého senátu) ze dne 10. 11. 2016, Signum Alfa Sped Kft. proti Nemzeti Adó- és Vámbivatal Kiemelt Adó- és Vám Föigazgatóság, věc C-446/15. ECLI:EU:C:2016:869 (blíže viz bod [39]).

40 Usnesení Soudního dvora (desátého senátu) ze dne 3. 9. 2020, Vikingo Fóvállalkozó Kft. proti Nemzeti Adó- és Vámbivatal Fellebbviteli Igargatósága, věc C-610/19. ECLI:EU:C:2020:673 (blíže viz bod [63]). 
Jak již bylo uvedeno shora, vnitrostátní správní orgány a soudy jsou povinny odmítnout přiznat nárok na odpočet, je-li na základě objektivních okolností prokázáno, že k uplatnění tohoto nároku došlo podvodně nebo zneužívajícím způsobem ${ }^{41}$. Není přitom př́pustné odepř́it nárok na odpočet daně osobě povinné k dani, která nevěděla nebo nemohla vědět, že dotyčné plnění bylo součástí daňového úniku - důvodem je fakt, že zavedení systému odpovědnosti bez zavinění by překračovalo rámec toho, co je nutné k ochraně plateb do veřejného rozpočtu ${ }^{42}$. SDEU nicméně ve svých závěrech připustil relevanci nedbalostní účasti na daňovém podvodu: toho se dopustí sama osoba povinná $\mathrm{k}$ dani v situaci, když věděla nebo měla vědět, že se předmětným plněním účastní plnění, které je součástí podvodu na DPH, jehož se dopustil dodavatel nebo jiný hospodářský subjekt nacházející se výše nebo níže v dodavatelském řetězci ${ }^{43}$. SDEU v tomto ohledu dovozuje, že osoba povinná k dani, která se daňového podvodu účastní nedbalostně, pomáhá pachatelům podvodu a stává se tak fakticky

41 Rozsudek Soudního dvora (prvního senátu) ze dne 18. 12. 2014, Staatssecretaris van Financiën proti Schoenimport „Italmoda“ Mariano Previti vof a Turbu.com BV Turbu.com Mobile Phone's BV proti Staatssecretaris van Financiën, spojené věci C-131/13, C-163/13 a C-164/13. ECLI:EU:C:2014:2455 (blíže viz bod [44]); Rozsudek Soudního dvora (třetího senátu) ze dne 6. 7. 2006, Axel Kittel proti Belgickému státu a Belgický stát proti Recolta Recycling SPRL, spojené věci C-439/04 a C-440/04. Dostupné z: Sbirka rozhodnutí. 2006, I-06161 (blíže viz bod [55]); Rozsudek Soudního dvora (třetího senátu) ze dne 6. 12. 2012, Bonike EOOD proti Direktor na Direkcija „Obžalvane i upravlenie na izpalnenieto" - Varna pri Centralno upravlenie na Nacionalnata agencija za prichodite, věc C285/11. ECLI:EU:C:2012:774 (blíže viz bod [37]); Rozsudek Soudního dvora (sedmého senátu) ze dne 13. 2. 2014, Maks Pen EOOD proti Direktor na Direkcia „Obžalvane i danačno-osiguritelna praktika“ Sofija, věc C18/13. ECLI:EU:C:2014:69 (blíže viz bod [26]).

42 Usnesení Soudního dvora (desátého senátu) ze dne 3. 9. 2020, Vikingo Fövállalkozó Kft. proti Nemzeti Adó- és Vámbivatal Fellebbviteli Igazgatósága, věc C-610/19. ECLI:EU:C:2020:673 (blíže viz bod [52]); Rozsudek Soudního dvora (třetího senátu) ze dne 12. 1. 2006, Optigen Ltd, Fulcrum Electronics Ltd a Bond House Systems Ltd proti Commissioners of Customs \& Excise, spojené věci C-354/03, C-355/03 a C-484/03. Dostupné z: Sbirka roz̧hodnutí. 2006, I-00483 (blíže viz body [52] a [55]); Rozsudek Soudního dvora (třetího senátu) ze dne 21. 6. 2012, Mahagében Kft proti Nemzeti Adó- és Vámbivatal Dél-dunántúli Regionális Adó Föigazgatósága a Péter Dávid proti Nemzeti Adó- és Vámbivatal Észak-alföldi Regionális Adó Föigazgatósága, spojené věci C-80/11 a C-142/11. ECLI:EU:C:2012:373 (blíže viz body [47] a [48]); Rozsudek Soudního dvora (třetího senátu) ze dne 6. 12. 2012, Bonik EOOD proti Direktor na Direkcija „Obžalvane i upravlenie na izpalnenieto" - Varna pri Centralno upravlenie na Nacionalnata agencija za prichodite, věc C285/11. ECLI:EU:C:2012:774 (blíže viz body [41] a [42]).

43 Rozsudek Soudního dvora (prvního senátu) ze dne 18. 12. 2014, Staatssecretaris van Financiën proti Schoenimport „Italmoda“ Mariano Previti vof a Turbu.com BV Turbu.com Mobile Phone's BV proti Staatssecretaris van Financiën, spojené věci C-131/13, C-163/13 a C-164/13. ECLI:EU:C:2014:2455 (blíže viz bod [50]); Rozsudek Soudního dvora (třetího senátu) ze dne 6. 7. 2006, Axel Kittel proti Belgickému státu a Belgický stát proti Recolta Recycling SPRL, spojené věci C-439/04 a C-440/04. Dostupné z: Sbírka roz̧hodnutí. 2006, I-06161 (blíže viz body [45], [46], [56], [60]); Rozsudek Soudního dvora (třetího senátu) ze dne 6. 12. 2012, Bonik EOOD proti Direktor na Direkcija „Obそ̌alvane i upravlenie na izpalnenieto“ - Varna pri Centralno upravlenie na Nacionalnata agencija za prichodite, věc C285/11. ECLI:EU:C:2012:774 (blíže viz body [38] až [40]); Rozsudek Soudního dvora (třetího senátu) ze dne 21. 6. 2012, Mahagében Kft proti Nemzeti Adó- és Vámbivatal Dél-dunántúli Regionális Adó Föigazgatósága a Péter Dávid proti Nemzeti Adó-és Vámbivatal Észak-alföldi Regionális Adó Fóigazgatósága, spojené věci C-80/11 a C-142/11. ECLI:EU:C:2012:373 (blíže viz body [45] a [46]). 
jejich spolupachatelem ${ }^{44}$. Co je hodné zvláštního zřetele, je fakt, že podmínkou dovození nedbalostní účasti na daňovém podvodu není dosažení prospěchu tímto subjektem, resp. takový člen řetězce je považován za osobu, která se podílí na takovém podvodu bez ohledu na to, zda má z následného prodeje zboží nebo využití služeb prospěch v rámci zdanitelných plnění, která uskutečnila na výstupu ${ }^{45}$. Judikatura SDEU i v tomto ohledu brojí proti prríliš extenzivnímu výkladu daného pravidla: podmínkou zachování nároku v prrípadě, že plnění je zatíženo daňovým podvodem, je přijetí takových opatření, která mohou být rozumně vyžadována pro to, aby subjekty zajistily, že jejich plnění nejsou součástí podvodu; bez ohledu na to, zda se jedná o podvod na DPH, nebo jiné podvody, musejí mít subjekty postupující s náležitou obezřetností zachován nárok na odpočet DPH odvedené na vstupu ${ }^{46}$. V jednom z novějších judikátů SDEU uzavírá, že vliv na odepření nároku na odpočet má i určitá nedbalost při plnění povinností řádné péče ${ }^{47}$. SDEU konstantně judikuje, že požadavek toho, aby subjekt jednal (byl) v dobré víre a přijal všechna opatření, která po něm mohou být rozumně požadována $\mathrm{k}$ zajištění toho, aby plnění, které uskutečňuje, nevedlo k jeho účasti na daňovém úniku, je unijním

44 Rozsudek Soudního dvora (třetího senátu) ze dne 6. 7. 2006, Axel Kittel proti Belgickému státu a Belgický stát proti Recolta Recycling SPRL, spojené věci C-439/04 a C-440/04. Dostupné z: Sbirka roz̧hodnutí. 2006, I-06161 (blíže viz bod [57]).

45 Rozsudek Soudního dvora (pátého senátu) ze dne 22. 10. 2015, PPUH Stehcemp sp.j Florian Stefanek, Janina Stefanek, Jaroslaw Stefanek, proti Dyrektor Izby Skarbowej w Lodz̨i, věc C-277/14. ECLI:EU:C:2015:719 (blíže viz bod [48]).

46 Rozsudek Soudního dvora (třetího senátu) ze dne 6. 7. 2006, Axel Kittel proti Belgickému státu a Belgický stát proti Recolta Recycling SPRL, spojené věci C-439/04 a C-440/04. Dostupné z: Sbirka rozhodnutí. 2006, I-06161 (blíže viz bod [51]); Rozsudek Soudního dvora (třetího senátu) ze dne 11. 5. 2006, Commissioners of Customs \& Excise a Attorney General proti Federation of Technological Industries a dalši, věc C-384/04. Dostupné z: Sbirka roz̧hodnutí. 2006, I-04191 (blíže viz bod [33]); Rozsudek Soudního dvora (třetího senátu) ze dne 21. 6. 2012, Mahagében Kft proti Nemzeti Adó- és Vámbivatal Dél-dunántúli Regionális Adó Föigazgatósága a Péter Dávid proti Nemzeti Adó- és Vámbivatal Észak-alföldi Regionális Adó Főigazgatósága, spojené věci C-80/11 a C-142/11. ECLI:EU:C:2012:373 (blǐže viz bod [53]); Rozsudek Soudního dvora (třetího senátu) ze dne 3. 10. 2019, Valsts ieñemumu dienests proti SLA „Altic", věc C-329/18. ECLI:EU:C:2019:831 (blíže viz bod [32]).

47 Usnesení Soudního dvora (desátého senátu) ze dne 14. 4. 2021, HR proti Finanzamt Wilmersdorf, věc C108/20. ECLI:EU:C:2021:266 (blíže viz body [26] a [27]).

„,26] Na rozdil od výkladu judikatury Soudního dvora provedenébo predkládajicim soudem z.judikatury uvedené $v$ bodech 21 až 25 tohoto usneseni zaprvé jasnè vyplývá, že poubá skutečnost, že osoba povinná k dani poř́dila z̧boži nebo služby, $i$ když néjakým zpuisobem véděla, že se timto pořizenim účastni plnèní, které je součásti úniku na DPH spáchanébo na vstupu v retézci dodáni zboži či poskytnuti služeb, je pro účly smèrnice 2006/112 považována z̧a účast na tomto úniku. Jak turdi nèmecká vláda, jediným pozitivním jednáním, keteré je rozhodujici pro odưvodnèni odepreni nároku na odpočet v takové situaci, je pořizeni tohoto z̧boži nebo těchto služeb. Kodivvodnèni takového odepreni tedy neni nutné prokázat, že se tato osoba povinná k dani nějakým zpuisobem aktivně podilela na uvedeném daňovém úniku, i kedyžjen aktivním nabádáním k. jeho spácháni nebo jebo usnadňováním. Rovněž je zucela irelevantní, že nez̧atajovala své dodavatelské v z̧taby ani dodavatele.

[27] To platí tím spiše, že podle této judikatury je z̧avena nároku na odpočet rovnéž osoba povinná k dani, která mèla vědèt, že se svým pořizenim účastni plnèni, které je součástí úniku na DPH spáchaného na vstupu v retězci dodání zboži nebo poskytnuti služeb. V takové situaci vede k odepreni nároke na odpočet určitá nedbalost pri plnèni povinností rádnépéce. " 
právem aprobováno ${ }^{48}$. Jinými slovy daňové neutrality, právní jistoty a ochrany legitimního očekávání se nemůže platně dovolávat osoba povinná $\mathrm{k}$ dani, která se úmyslně podílela na daňovém úniku a ohrozila tak fungování společného systému $\mathrm{DPH}^{49}$. V žádném př́padě však správce daně nemůže od osoby povinné $\mathrm{k}$ dani vyžadovat, aby složitě a důkladně prověřovala svého dodavatele, a fakticky tak na ni přenést kontrolní úkony, které má vykonávat on sám ${ }^{50}$. Obecně platí, že v př́ípadě existence náznaků vzbuzujících podezření, že došlo k nesrovnatelnosti nebo podvodu, lze samozřejmě od obezřetného subjektu v závislosti na okolnostech projednávaného př́padu vyžadovat, aby si zjistil informace o druhém subjektu, u něhož zamýšlí nakoupit zboží či služby, za účelem ujištění se o jeho věrohodnosti ${ }^{51}$. Na druhou stranu dle závěrů SDEU nemůže správce daně vyžadovat, aby „osoba povinná k dani, která chce uplatnit nárok na odpočet DPH, ověrovala, zda vystavitel faktury týkajici se z̧boži a služeb, na které je uplatňován tento nárok, je v postavení osoby povinné k dani, zda má k dispozici dotčené zboži a je s to uvedené zboži dodat a že splnil své povinnosti obledně podáni daňového priznáni a úhrady DPH, a tím se ujistila, že nedošlo k nesrovnalostem ř podvodu u subjektu na vstupu, a dále aby v tomto obledu mèla k dispozici potrebné doklady “52. To je bezesporu požadavek související v řadě ohledů s neveřejností správy daní: správce daně může ze své pozice získat údaje a informace, ke kterým daňový subjekt př́istup nemá. $\mathrm{V}$ tomto ohledu judikatura SDEU, uvádí, že: „... daňové správě, která konstatovala podvody nebo nesrovnalosti, jichž se dopustil vystavitel predmétné faktury, př̀islǔsi, aby s obledem na objektivni skutečnosti a aniž by po príjemci této faktury požadovala ovérení, která mu neprìslušeji, prokázala, že tento príjemce vèděl nebo mèl vèdèt, že plnèni uplatňované k odìvodnèni

48 Rozsudek Soudního dvora (desátého senátu) ze dne 17. 10. 2019, Unitel Sp. z o.o. w Warszawie proti Dyrektor Ižby Skarbowej w Warszawie, věc C-653/18. ECLI:EU:C:2019:876 (bliže viz bod [33]).

49 Rozsudek Soudního dvora (velkého senátu) ze dne 7. 12. 2010, Trestní rízeneni proti R., věc C-285/09. Dostupné z: Sbirka rozhodnutí. 2010, I-12605 (bliže viz bod [54]).

50 Usnesení Soudního dvora (desátého senátu) ze dne 3. 9. 2020, Vikingo Fóvállalkơó Kft. proti Nemzeti Adó- és Vámbivatal Fellebbviteli Igazgatósága, věc C-610/19. ECLI:EU:C:2020:673 (bliže viz bod [56]); rozsudek Soudního dvora (druhého senátu) ze dne 19. 10. 2017, SC Paper Consult SR L proti Direcţia Regională a Finanțelor Publice Cluj-Napoca a Administrația Județeană a Finanțelor Publice Bistrița Năsăud, věc C-101/16. ECLI:EU:C:2017:775 (blǐže viz bod [51]).

51 Rozsudek Soudního dvora (devátého senátu) ze dne 18. 5. 2017, UAB „Litdana“ proti Valstybine mokesčin inspekcija prie Lietuvos Respublikos finansu ministerijos, věc C-624/15. ECLI:EU:C:2017:389 (blíže viz bod [39]); Rozsudek Soudního dvora (třetího senátu) ze dne 21. 6. 2012, Mahagében Kft proti Nemzeti Adó- és Vámbivatal Dél-dunántúli Regionális Adó Fóigazgatósága a Péter Dávid proti Nemreti Adó- és Vámbivatal Észake-alföldi Regionális Adó Fóigazgatósága, spojené věci C-80/11 a C-142/11. ECLI:EU:C:2012:373 (blǐže viz bod [60]); Usnesení Soudního dvora (desátého senátu) ze dne 3. 9. 2020, Vikingo Fövállalkozó Kft. proti Nemzeti Adó-és Vámbivatal Fellebbviteli Igazgatósága, věc C-610/19. ECLI:EU:C:2020:673 (blíže viz bod [55]).

52 Rozsudek Soudního dvora (trretího senátu) ze dne 21. 6. 2012, Mahagében Kftproti Nemzeti Adó-és Vámbivatal Dél-dunántúli Regionális Adó Föigazgatósága a Péter Dávid proti Nemzeti Adó- és Vámbivatal Észalk-alföldi Regionális Adó Fóigazgatósága, spojené věci C-80/11 a C-142/11. ECLI:EU:C:2012:373 (bliže viz bod [61]). 
nároku na odpočet bylo součásti podvodu v oblasti DPH. "53 Stále však platí, že příslušným tuzemským daňovým správám zůstává, při reflexi norem unijního práva, značná míra diskrece. To se týká i způsobů a pravidel, jakým mají být prováděny důkazy týkající se podvodů na DPH, prričemž objektivní okolnosti musí prokázat př́slušná vnitrostátní daňová správa v souladu s důkazními pravidly vnitrostátního práva ${ }^{54}$.

\section{Diskuse a závěr}

S ohledem na provedenou analýzu judikatury SDEU vyplývá, že SDEU nepodává explicitní a taxativní definici daňového podvodu (úniku) - vymezuje však znaky a okolnosti, které pro existenci daňového podvodu (úniku) svědčí. Z judikatury přiléhavé ke kladené výzkumné otázce je evidentní, že daňový únik je možné spojovat s širokou množinou skutečností (nevedení účetnictví, zatajení dodání zboží, zatajení přímmo̊, nepodání daňového přiznání, nezaplacení splatné daně správním orgánům, atd.). Uvedené skutečnosti ovšem musí působit v souvislosti s cílem vyhnutí se placení daně (srov. Astone, C-332/15, bod 55, a SC Paper Consult, C-101/16, bod 56). Judikatura SDEU klade důraz na to, aby každé nesplnění formálních požadavků ze strany osob povinných k dani nebylo klasifikováno za podvodné jednání (viz např. Vikingo, C-610/19, bod 63). Prokázání cíle spočívajícího v záměrném vyhnutí se placení daně spočívá pochopitelně výhradně na daňových orgánech. Jakým způsobem mají výše uvedený cíl daňové orgány ověřit, SDEU konkrétně neuvádí, nicméně lze ze souhrnu judikatury z této oblasti dojít k závěru, že daňové orgány by se měly zabývat určitými nesrovnalostmi u subjektů, které jsou součástí dodavatelsko-odběratelského řetězce (viz např. Signum Alfa Sped, C-446/15, bod 39). Judikatura SDEU, pokud hovoří o podvodném dodavatelsko-odběratelském řetězci, tak žádným způsobem tento řetězec neomezuje z teritoriálního pohledu (viz např. Italmoda, C-131/13, bod 69). K daňovému podvodu může dojít i v jiném členském státě či ve třetí zemi.

Z judikatury SDEU rovněž jednoznačně vyplývá, že nárok na odpočet daně nelze odepřít komukoli, kdo byl součástí podvodného řetězce. Judikatura SDEU klade důraz na to, aby byl proveden tzv. vědomostní test, jehož výsledky lze interpretovat následovně. Nárok na odpočet daně nelze odeprrít osobě povinné $\mathrm{k}$ dani, která nevěděla nebo nemohla vědět, že dotyčné plnění bylo součástí daňového úniku. Zavedení systému odpovědnosti bez zavinění by totiž překračovalo rámec toho, co je nezbytné k ochraně plateb do veřejného rozpočtu (viz např. Mahagében, body 47 a 48). Judikatura SDEU shrnuje, že je zcela

53 Rozsudek Soudního dvora (třetího senátu) ze dne 3. 10. 2019, Valsts ieñemumu dienests proti SLA „Altic", věc C-329/18. ECLI:EU:C:2019:831 (blíže viz bod [31]); Rozsudek Soudního dvora (pátého senátu) ze dne 22. 10. 2015, PPUH Stehcemp sp. j Florian Stefanek, Janina Stefanek, Jaroslaw Stefanek proti Dyrek.tor Izby Skarbowej w Lodzi, věc C-277/14. ECLI:EU:C:2015:719 (blíže viz bod [50]).

54 Rozsudek Soudního dvora (šestého senátu) ze dne 4. 6. 2020, SC C.F. SR L proti A.J.F.P.M. a D.G.R.F.P.C, věc C-430/19. ECLI:EU:C:2020:429 (blíže viz bod [45]); Rozsudek Soudního dvora (pátého senátu) ze dne 16. 10. 2019, Glencore Agriculture Hungary Kft. proti Nemzeti Adó- és Vámbivatal Fellebbviteli Igargatósága, věc C-189/18. ECLI:EU:C:2019:861. (blíže viz bod [37]). 
na příslušném daňovém orgánu, aby prokázal, že osoba povinná $\mathrm{k}$ dani (př́ijemce plněnî) uplatňující si nárok na odpočet daně z prijiatého plnění věděla nebo měla vědět, že toto plnění bylo součástí podvodu (např. PPUH Stehcemp, C-277/14, bod 50). Z výše uvedeného je žrejmé, že judikatura nerozlišuje vědomé a nevědomé účastníky podvodu. $\mathrm{K}$ nevědomým účastníkům podvodu judikatura SDEU uvádí, že de facto svou nedbalostí napomáhají účastníkům podvodu, a proto se stávají spolupachateli (viz Kittel, spojené věci C-439/04 a C-440/04, bod 57). Již zmíněný vědomostní test spočívá v identifikaci objektivních skutečností, ze kterých vyplyne závěr bud' o vědomosti, či nevědomosti osoby, jež přijala dotčené plnění, o účasti na daňovém podvodu. Autoři článku uzavírají, že ačkoli v judikatuře SDEU nejsou předmětné objektivní skutečnosti podrobněji popsány, lze prostřednictvím základní logiky dojít k závěru, že pokud cílem vědomostního testu je učinit závěr o vědomosti určitého subjektu o podvodném jednání, tak jednotlivé objektivní skutečnosti musí být okolnosti ve sféře vlivu dotčeného subjektu, tudíž se v zásadě bude jednat o okolnosti vyplývající z obchodních vztahů s přímým dodavatelem či odběratelem. Judikatura SDEU ve zde řešené věci žádným způsobem nerozlišuje situace, ve kterých by se mělo rozdílným zpơsobem nahlížet na situace, kdy $\mathrm{k}$ daňovému úniku dojde u přímého dodavatele př́jemce dotčeného plnění či u jiného hospodářského subjektu (viz např. Italmoda, C-131/13, bod 50).

Z judikatury SDEU dále vyplývá, že jednotlivé osoby povinné k dani nemusí detailně ověřovat všechny své obchodní partnery. Nicméně od obezřetného subjektu lze vyžadovat, aby si zjistil určité informace o svém dodavateli, a to zejména v př́padě, kdy existují náznaky o určitých nesrovnalostech vzbuzujících podežrení o podvodu (viz např. „Litdana" $U A B$, C-624/15, bod 39). Unijní právo požaduje, aby osoby povinné k dani účastnící se ekonomických transakcí na trhu zboží a služeb jednaly v dobré víre, a to k zajištění toho, že se v rámci svých obchodních transakcí nestanou účastníky daňového podvodu (Unitel, C-653/18, bod 33). Jestliže tyto osoby přijmou veškerá rozumná opatření, která od nich mohou být vyžadována, aby se nestaly účastníky podvodu, musí být jejich nárok na odpočet daně zachován. SDEU závěrem k této věci dále podotýká, že nelze požadovat po př́jemci dotčeného plnění (jež uplatňuje př́slušný nárok na odpočet daně), aby v rámci své činnosti prováděl ověření, která této osobě neprúislušejí (resp. př́slušejí správnímu orgánu; viz např. Paper Consult, C-101/16, bod 51).

Pro úplnost autoři článku dodávají, že boj proti daňovým únikưm, vyhýbání se daňovým povinnostem a prípadným zneužitím je cílem uznaným a podporovaným Směrnicí DPH (viz zejména rozsudky Halifax a další, C-255/02, bod 71; Kittel, spojené věci C-439/04 a C-440/04, bod 54, jakož i Mahagében, spojené věci C-80/11 a C-142/11, bod 41). Ačkoli předmětný článek se předně zabývá otázkami spojenými s nárokem na odpočet daně, který je zásadní pro princip neutrality, tak je třeba zdůraznit, že vnitrostátní správní orgány a soudy v zásadě musí odmítnout přiznat všechny nároky stanovené ve Směrnici o DPH, které jsou uplatňovány podvodně nebo zneužívajícím způsobem, bez ohledu na to, zda se jedná o nárok na odpočet, osvobození nebo vrácení DPH (viz Italmoda, C-131/13, bod 44). Dále 
je třeba zdůraznit, že odepření nároku na odpočet je výjimkou ze základní zásady, kterou tento nárok představuje, a proto je na daňových orgánech, aby právně dostačujícím způsobem prokázaly, že nastaly objektivní okolnosti, na základě kterých se lze domnívat, že osoba povinná $\mathrm{k}$ dani věděla nebo měla vědět, že plnění, jehož se dovolává na podporu svého nároku na odpočet, je součástí takového úniku (viz Vikingo, C-610/19 bod 57, Biosafe Induistria de Reciclagens ${ }^{55}$, C-8/17, bod 39, a Glencore Agriculture Hungary, C-189/18, bod 36).

$\mathrm{V}$ rámci provedeného výzkumu autoři identifikovali řadu dalších a souvisejících otázek, které navazují na shora uvedené závěry a výsledky. Je zřejmé, že hodnou dalšího zkoumání ve smyslu identifikace a systematizace judikatorních závěrů SDEU jsou pravidla týkající se subjektů, které lze postihnout v rámci identifikovaného a popsaného řetězce. Autoři vnímají danou otázku jako jednu z klíčových pro hodnocení otázek spojených s udržením nároku na odpočet na straně daňového subjektu. Jak vyplynulo z dosavadního šetření, jde o významnou dílčí otázku s jasnou vazbou k:

a) zachování nároku na odpočet DPH coby klíčového atributu neutrality této daně,

b) pojmovým znakům tzv. „chybějící daněcc56.

Navazující výzkum bude zaměřen na identifikaci podmínek, které musí být splněny pro to, aby byl daňovému subjektu odňat nárok na odpočet daně i po splnění hmotněprávních podmínek ${ }^{57}$ nároku na odpočet daně. Dílčí otázky pak budou zaměřeny na systematizaci a hodnocení skutkových okolností a jejich dopadu, identifikaci obecných a speciálních pravidel a zhodnocení souladnosti rozhodovací praxe SDEU s rozhodovací praxí NSS ČR.

Autoři závěrem poukazují na to, že problematika odnětí nároku na odpočet DPH $\mathrm{v}$ důsledku zatížení transakce daňovým podvodem je problematikou komplexní, kdy v konkrétním případě je vždy zapotřebí brát v potaz příslušný skutkový stav a veškeré okolnosti př́padu - judikaturní závěry tak nelze aplikovat automaticky a bezvýhradně58. Stejně tak je nutné se vystř́hat toho, aby byly dílčí aspekty konkrétního př́padu a jednotlivé právní názory vnímány a hodnoceny izolovaně pouze ve vztahu k dílčí podmínce (viz tříkrokový Axel Kittel test v textu prŕíspěvku výše). Je bezesporu zapotřebí uvažovat i přesah a význam při prokazování a naplnění dalších podmínek. Pro praxi je typické, že jednotlivé skutkové okolnosti nejsou samy o sobě dostatečně způsobilé prokázání některé z podmínek ,testu na podvod“ (mnohdy nebývají svou podstatou ani nezákonné). Je třeba je vnímat jako střípky: „,... do mozaiky celkově utvárejúcí podvod na DPH. “59

55 Rozsudek Soudního dvora (sedmého senátu) ze dne 12. 4. 2018, Biosafe - Indústria de Reciclagens SA proti Flexipiso-Pavimentos $S A$, věc C-8/17. ECLI:EU:C:2018:249.

56 Jde rovněž o jeden z klíčových aspektů, který je hoden samostatného zkoumání.

57 Blíže viz \ 72 a násl. zákona č. 235/2004 Sb., o dani z prridané hodnoty, ve znění pozdějších předpisů.

58 K výstižnému hodnocení viz nap̌r. rozsudek NSS ČR ze dne 30. 1. 2018, sp. zn. 5 Afs 60/2017.

59 Rozsudek NSS ČR ze dne 20. 1. 2021, sp. zn. 10 Afs 206/2020. 